\title{
Drug-drug interactions between sucroferric oxyhydroxide and losartan, furosemide, omeprazole, digoxin and warfarin in healthy subjects
}

\author{
Edward Chong • Veena Kalia • Sandra Willsie • \\ Peter Winkle
}

Received: 1 November 2013/ Accepted: 8 March 2014/Published online: 4 April 2014

(c) The Author(s) 2014. This article is published with open access at Springerlink.com

\begin{abstract}
Background The novel iron-based phosphate binder sucroferric oxyhydroxide is being investigated for the treatment of hyperphosphatemia. Patients with chronic kidney disease often have multiple comorbidities that may necessitate the daily use of several types of medication. Therefore, the potential pharmacokinetic drug-drug interactions between sucroferric oxyhydroxide and selected drugs commonly taken by dialysis patients were investigated.

Methods Five Phase I, single-center, open-label, randomized, three-period crossover studies in healthy volunteers investigated the effect of a single dose of sucroferric oxyhydroxide $1 \mathrm{~g}$ (based on iron content) on the pharmacokinetics of losartan $100 \mathrm{mg}$, furosemide $40 \mathrm{mg}$, omeprazole $40 \mathrm{mg}$, digoxin $0.5 \mathrm{mg}$ and warfarin $10 \mathrm{mg}$. Pharmacokinetic parameters [including area under the plasma concentrationtime curve (AUC) from time 0 extrapolated to infinite time $\left(\mathrm{AUC}_{0-\infty}\right)$ and from 0 to $\left.24 \mathrm{~h}\left(\mathrm{AUC}_{0-24}\right)\right]$ for these drugs were determined: alone in the presence of food; with sucroferric oxyhydroxide in the presence of food; $2 \mathrm{~h}$ after food and sucroferric oxyhydroxide administration.

Results Systemic exposure based on $\mathrm{AUC}_{0-\infty}$ for all drugs, and $\mathrm{AUC}_{0-24}$ for all drugs except omeprazole (for
\end{abstract}

Clinical trial registration numbers: NCT01477411, NCT01324752, NCT01438359, NCT01452906, NCT01477424.

\section{E. Chong $(\varangle) \cdot$ V. Kalia}

Vifor Pharma, Clinical Development, Aspreva International Ltd., 1203, 4464 Markham Street, Victoria, BC V8Z 7X8, Canada

e-mail: edward.chong@viforpharma.com

\section{S. Willsie}

PRA International, Lenexa, KS, USA

P. Winkle

Anaheim Clinical Trials, Anaheim, CA, USA which AUC 0-8 h was measured), was unaffected to a clinically significant extent by the presence of sucroferric oxyhydroxide, irrespective of whether sucroferric oxyhydroxide was administered with the drug or $2 \mathrm{~h}$ earlier.

Conclusions There is a low risk of drug-drug interactions between sucroferric oxyhydroxide and losartan, furosemide, digoxin and warfarin. There is also a low risk of drug-drug interaction with omeprazole (based on $\mathrm{AUC}_{0-\infty}$ values). Therefore, sucroferric oxyhydroxide may be administered concomitantly without the need to adjust the dosage regimens of these drugs.

Keywords Chronic kidney disease . Hyperphosphatemia - Sucroferric oxyhydroxide . Pharmacokinetics · Phase I

\section{Introduction}

One of the serious and common clinical consequences of chronic kidney disease (CKD) is hyperphosphatemia, which is associated with CKD-mineral bone disorder [1], and increased risk of cardiovascular events [2] and mortality [36]. As a result, patients on dialysis often require phosphate binding agents to control serum phosphorus concentrations.

The novel polynuclear iron (III)-oxyhydroxide phosphate binder sucroferric oxyhydroxide is being investigated for the treatment of hyperphosphatemia. It is formulated as a chewable tablet that may be taken without water. In Phase I clinical studies, sucroferric oxyhydroxide was shown to be associated with minimal iron absorption through the gastrointestinal (GI) tract, and to be well tolerated [7, 8]. A Phase II dose-finding study demonstrated that sucroferric oxyhydroxide doses of 1.0-2.5 g/day (based on iron content) significantly lowered serum 
phosphorus concentrations [9]. A Phase III study in patients with hyperphosphatemia undergoing hemo- or peritoneal dialysis was recently undertaken [10]. In this study, patients $(n=1,059)$ were randomized to receive sucroferric oxyhydroxide 1.0-3.0 g/day or sevelamer 4.8-14.4 g/day. It was shown that sucroferric oxyhydroxide was non-inferior to sevelamer in terms of serum phosphorus control over the first 12 weeks of treatment, maintained its phosphorus-lowering effect over 52 weeks with a lesser pill burden than sevelamer, and was associated with reduced non-adherence to treatment [10, 11].

Patients with CKD often have multiple comorbidities, including cardiovascular disease, hypertension and diabetes, which may necessitate the use of several different types of daily medications $[12,13]$. In vitro studies have identified a few potential interactions between sucroferric oxyhydroxide and some common medications (unpublished data) prescribed to patients with CKD. Therefore, a program of human in vivo pharmacokinetic (PK) drug-drug interaction (DDI) studies between sucroferric oxyhydroxide and several common medications was undertaken. Here we report data from five separate Phase I clinical DDI studies undertaken in healthy adults of sucroferric oxyhydroxide administered with medications selected based on adsorption of these medications onto sucroferric oxyhydroxide from in vitro investigations. Digoxin and warfarin did not show interactions in the in vitro investigations, but were chosen due to their narrow therapeutic window. The primary objective of these studies was to assess whether there was any effect of sucroferric oxyhydroxide on medication exposure [area under the plasma concentration-time curve from time
0-24 h ( $\left.\mathrm{AUC}_{0-24}\right)$; AUC from time 0 extrapolated to infinite time $\left(\mathrm{AUC}_{0-\infty}\right)$; peak serum concentration $\left(\mathrm{C}_{\max }\right)$; time to $\mathrm{C}_{\max }\left(\mathrm{T}_{\max }\right)$ and terminal half-life $\left.\left(\mathrm{t}_{1 / 2}\right)\right]$. Adverse event profiles and routine biochemical/hematological laboratory tests were also assessed.

\section{Subjects and methods}

Study design and interventions

Five Phase I, single-center, open-label, randomized, threeperiod crossover studies investigated the PK effect of sucroferric oxyhydroxide (single dose of $1 \mathrm{~g}$, based on iron content) on the following medications: losartan potassium $\left(\right.$ Cozaar $^{\circledR} 100 \mathrm{mg}$ ), furosemide (Lasix ${ }^{\circledR} 40 \mathrm{mg}$ ), omeprazole (Prilosec ${ }^{\circledR} 40 \mathrm{mg}$ ), digoxin (Lanoxin ${ }^{\circledR} 0.5 \mathrm{mg}$ ) and warfarin (Coumadin ${ }^{\circledR} 10 \mathrm{mg}$ ). The doses of these drugs are based on the approved doses and those that are commonly used in clinical practice and/or have been used in PK interaction studies. The dose of sucroferric oxyhydroxide is the maximum single dose proposed for clinical use. Each study comprised a screening visit, 12 safety and PK visits, two washout periods (7 days each) and one follow-up visit 2 weeks after the last administration of study medication.

Subjects were randomized $(1: 1: 1)$ to one of three treatment groups by sequentially following a randomization code list. Treatment Group 1 began with 'Schedule 1' dosing, Treatment Group 2 began with 'Schedule 2' dosing, and Treatment Group 3 began with 'Schedule 3' dosing (Table 1). After a 7-day washout period, subjects

Table 1 Study drug administration

\begin{tabular}{|c|c|c|c|c|c|c|}
\hline $\begin{array}{l}\text { Dosing } \\
\text { schedule }\end{array}$ & Day -1 & Day 1 & Day $8 \% 11$ & Day $9 \% 12$ & Day $16^{\mathrm{a}} / 22$ & Day $17^{\mathrm{a}} / 23$ \\
\hline 1 & $\begin{array}{l}\text { Sucroferric } \\
\text { oxyhydroxide } \text { TID }^{b}\end{array}$ & $\begin{array}{l}\text { Sucroferric oxyhydroxide } \\
\text { single dose }^{\mathrm{c}} \\
\text { Test drug }^{\mathrm{d}}\end{array}$ & & Test drug ${ }^{\mathrm{d}}$ & $\begin{array}{l}\text { Sucroferric } \\
\text { oxyhydroxide } \text { TID }^{\mathrm{b}}\end{array}$ & $\begin{array}{l}\text { Sucroferric } \\
\text { oxyhydroxide } \\
\text { single dose } \\
\text { Test drug }\end{array}$ \\
\hline 2 & & Test drug $^{\mathrm{d}}$ & $\begin{array}{l}\text { Sucroferric } \\
\text { oxyhydroxide } \text { TID }^{\mathrm{b}}\end{array}$ & $\begin{array}{l}\text { Sucroferric } \\
\text { oxyhydroxide } \\
\text { single dose } \mathrm{e}^{\mathrm{c}} \\
\text { Test drug }\end{array}$ & $\begin{array}{l}\text { Sucroferric } \\
\text { oxyhydroxide } \text { TID }^{\mathrm{b}}\end{array}$ & $\begin{array}{l}\text { Sucroferric } \\
\text { oxyhydroxide } \\
\text { single dose } \\
\text { Test drug }^{\mathrm{d}}\end{array}$ \\
\hline 3 & $\begin{array}{l}\text { Sucroferric } \\
\text { oxyhydroxide } \text { TID }^{b}\end{array}$ & $\begin{array}{l}\text { Sucroferric oxyhydroxide } \\
\text { single dose } \\
\text { Test drug }\end{array}$ & $\begin{array}{l}\text { Sucroferric } \\
\text { oxyhydroxide } \text { TID }^{\mathrm{b}}\end{array}$ & $\begin{array}{l}\text { Sucroferric } \\
\text { oxyhydroxide } \\
\text { single dose } \\
\text { Test drug }\end{array}$ & & Test drug ${ }^{\mathrm{d}}$ \\
\hline
\end{tabular}

\footnotetext{
${ }^{\text {a }}$ Warfarin interaction study only

b Sucroferric oxyhydroxide $1 \mathrm{~g}$ (based on iron content) three times daily (TID; 6 tablets/day; total daily dose of 3 g/day, based on iron content) given with meals

c Sucroferric oxyhydroxide $1 \mathrm{~g}$ (based on iron content) given as a single dose of two tablets with breakfast

d Test drug single dose given with breakfast

e Test drug single dose given $2 \mathrm{~h}$ after breakfast/sucroferric oxyhydroxide administration but $\geq 1 \mathrm{~h}$ before the next meal
} 
from Treatment Group 1 crossed over to receive 'Schedule 2' dosing, Treatment Group 2 crossed over to receive 'Schedule 3' dosing, and Treatment Group 3 crossed over to receive 'Schedule 1' dosing. After a further 7-day washout period, subjects from Treatment Group 1 crossed over to receive 'Schedule 3' dosing, Treatment Group 2 crossed over to receive 'Schedule 1' dosing, and Treatment Group 3 crossed over to receive 'Schedule 2' dosing.

\section{Participants}

Subjects eligible for these studies were healthy male or female volunteers aged 20-50 years, and with a body mass index of $18-32 \mathrm{~kg} / \mathrm{m}^{2}$. The subjects had to provide written informed consent before the commencement of any studyspecific procedures. All protocols were approved by an independent Review Board. Subjects were ineligible for the studies if they had participated in a clinical trial with an investigational drug or device $\leq 3$ months before screening, if they had a history of clinically significant disorders or drug hypersensitivity, had a history of recurrent infectious diseases or major illness $\leq 30$ days before screening, used nicotine $\leq 30$ days before Study Day -1 , presented with clinically significant abnormal findings on any screening assessments, took any medication $\leq 2$ weeks before Study Day -1 , had a clinically relevant history of drug or alcohol misuse, suffered any significant blood loss or blood donation $\leq 3$ months before Study Day -1 , or if they were pregnant or did not use adequate contraceptive precautions. No non-study medications, nicotine, alcohol or drugs of abuse were permitted during the study.

\section{Outcomes}

The primary endpoints of the studies were $\mathrm{AUC}_{0-24}$, $\mathrm{AUC}_{0-\infty}, \mathrm{C}_{\max }, \mathrm{T}_{\max }$, and $\mathrm{t}_{1 / 2}$ for each of the study medications. These endpoints were analyzed for the two active enantiomers of warfarin ( $\mathrm{R}$ - and S-forms) and also for the active metabolite of losartan (EXP 3174). Safety endpoints included adverse events and routine biochemical/hematological laboratory tests.

\section{Sample sizes}

For the studies involving losartan and furosemide, 36 and 42 subjects, respectively, were considered to be adequate in terms of demonstrating bioequivalence for the primary analysis of $\mathrm{AUC}_{0-24}$, and the sample sizes were not based on statistical assumptions.

For the omeprazole and digoxin studies, a total of 36 evaluable subjects each was judged to be sufficient to demonstrate the equivalence in a crossover design with a power of $84 \%$, considering a standard deviation (SD) of the difference of 0.43 (in the $\log$ scale), a 1-sided $\alpha$ of 0.05 , an expected ratio of 1 , and the bioequivalence limits of 80-125\%.

For the warfarin study, at least 36 evaluable subjects were considered sufficient to demonstrate the bioequivalence in a crossover design with a power of more than $95 \%$, considering a SD of the difference of 0.35 (in the $\log$ scale), a 1 -sided $\alpha$ of 0.05 , an expected ratio of 1 , and the bioequivalence limits of 80-125\%.

Statistical methods

PK parameters were calculated using non-compartmental methods with WinNonlin ${ }^{\circledR}$ Professional Version 5.1.1 or higher (Pharsight Corp., Mountain View, CA, USA). PK computations were performed in $\mathrm{SAS}^{\circledR}$ Version 9.1 or higher. The plasma PK parameters were estimated from the concentration-time profiles for all PK population subjects. In estimating the PK parameters, values that were below the lower limit of quantification (LLOQ) at the beginning of the profile were set to 0 . Lower limit of quantification values that occurred after the first quantifiable point were considered missing. Values that were embedded between LLOQs, or quantifiable values occurring after two or more LLOQs, were set to missing at the discretion of the pharmacokineticist. Descriptive statistics were used to summarize the calculated PK parameters by treatment. Missing PK parameter data were not imputed. $T_{\max }$ and $t_{1 / 2}$ were analyzed using the nonparametric Wilcoxon signed-rank test. To assess the effect of sucroferric oxyhydroxide on the PK of test medications (or the active metabolite), an analysis of variance (ANOVA) with fixed treatment, period, sequence, and subject within sequence was applied to natural logarithmtransformed $\mathrm{AUC}_{0-24}, \mathrm{AUC}_{0-\infty}$, and $\mathrm{C}_{\text {max }}$. For omeprazole, analysis of $\mathrm{AUC}_{0-24}$ was planned but drug levels were below the limit of quantitation in all subjects by $8-12 \mathrm{~h}$. Therefore, AUC 0-8 h $\left(\mathrm{AUC}_{0-8}\right)$ was calculated instead of $\mathrm{AUC}_{0-24}$.

Bioequivalence criteria for log-transformed parameters were defined as 80-125\%. No clinically significant differences were concluded when $90 \%$ confidence intervals (CIs) for exposure ratios fell within these bioequivalence criteria.

\section{Results}

Subject demographics and disposition

In total, 213 subjects were randomized across the five studies, of whom 210 received study medication and were included in the safety population. Overall, 200 subjects received treatment in at least two of the three dosing schedules and were eligible for PK analysis $(n=36$ for 
Table 2 Summary of demographics for randomized subjects across the five Phase I studies

\begin{tabular}{|c|c|c|c|c|c|}
\hline $\begin{array}{l}\text { Demographic } \\
\text { characteristics }\end{array}$ & $\begin{array}{l}\text { Losartan } \\
(\mathrm{n}=41)\end{array}$ & $\begin{array}{l}\text { Furosemide } \\
(\mathrm{n}=41)\end{array}$ & $\begin{array}{l}\text { Omeprazole } \\
(n=43)\end{array}$ & $\begin{array}{l}\text { Digoxin } \\
(\mathrm{n}=42)\end{array}$ & $\begin{array}{l}\text { Warfarin } \\
(\mathrm{n}=43)\end{array}$ \\
\hline \multicolumn{6}{|l|}{ Sex, n $(\%)$} \\
\hline Male & $26(63.4)$ & $28(68.3)$ & $22(51.2)$ & $21(50.0)$ & $26(60.5)$ \\
\hline Female & 15 (36.6) & $13(31.7)$ & $21(48.8)$ & $21(50.0)$ & $17(39.5)$ \\
\hline \multicolumn{6}{|l|}{ Race, n (\%) } \\
\hline White & $31(75.6)$ & $26(63.4)$ & $30(69.8)$ & $27(64.3)$ & $26(60.5)$ \\
\hline Black/African American & $3(7.3)$ & $5(12.2)$ & $5(11.6)$ & $10(23.9)$ & $15(34.9)$ \\
\hline Asian & $7(17.1)$ & $10(24.4)$ & $7(16.3)$ & $4(9.5)$ & $1(2.3)$ \\
\hline Other & $0(0.0)$ & $0(0.0)$ & $1(2.3)$ & $1(2.4)$ & $1(2.3)$ \\
\hline \multicolumn{6}{|l|}{ Ethnicity, n (\%) } \\
\hline Not Hispanic or Latino & $24(58.5)$ & $28(68.3)$ & $26(60.5)$ & $24(57.1)$ & $41(95.3)$ \\
\hline Hispanic or Latino & $17(41.5)$ & $13(31.7)$ & $17(39.5)$ & $18(42.9)$ & $2(4.7)$ \\
\hline Age, mean (SD) years & $31.8(9.5)$ & $31.8(8.5)$ & $31.4(9.6)$ & $31.5(8.6)$ & $30.1(7.8)$ \\
\hline
\end{tabular}

$S D$ standard deviation

losartan, $\mathrm{n}=41$ for furosemide, $\mathrm{n}=39$ for omeprazole, $\mathrm{n}=42$ for digoxin, and $\mathrm{n}=42$ for warfarin).

In total, 193 subjects completed the studies and 17 withdrew. Of the subjects who withdrew before randomization, nine did so by their own decision, six were found to have taken drugs/alcohol; following randomization, one subject was withdrawn as a result of an adverse event (rhabdomyolysis), and a second subject was withdrawn as the result of an administrative decision.

Patient demographics at baseline were similar between the treatment groups (Table 2).

\section{Pharmacokinetic results}

$A U C_{O-24}$ and $A U C_{O-\infty}$

The systemic exposure of all test medications was unaffected to a clinically significant extent by the presence of sucroferric oxyhydroxide (i.e., $90 \%$ CIs were within the bioequivalence range), based on $\mathrm{AUC}_{0-\infty}$ (Table 3). Moreover, the systemic exposure of medications was unaffected irrespective of whether sucroferric oxyhydroxide was administered with the medication or $2 \mathrm{~h}$ earlier.

The systemic exposure, based on $\mathrm{AUC}_{0-24}$, for all drugs except omeprazole (for which $\mathrm{AUC}_{0-8}$ was measured) was also largely unaffected by the presence of sucroferric oxyhydroxide, irrespective of whether sucroferric oxyhydroxide was administered with the medication or $2 \mathrm{~h}$ earlier.

The $\mathrm{AUC}_{0-8}$ value of omeprazole was increased when sucroferric oxyhydroxide was administered $2 \mathrm{~h}$ before the medication, as the upper bound $90 \%$ CI was outside the bioequivalence range, relative to that obtained in the absence of sucroferric oxyhydroxide.

The extent of formation of the active metabolite of losartan, EXP 3174, was also unaffected by sucroferric oxyhydroxide, with AUC parameters being within the bioequivalence range.

$C_{\text {max }}$

Sucroferric oxyhydroxide had no clinically significant effect on the $\mathrm{C}_{\max }$ of R-warfarin, S-warfarin or EXP 3174 (i.e., $90 \%$ CIs were within the bioequivalence range) (Table 3). However, the $\mathrm{C}_{\max }$ values of losartan, furosemide and omeprazole were decreased (lower bound $90 \%$ CIs were outside the bioequivalence range) relative to those in the absence of sucroferric oxyhydroxide.

Furthermore, when sucroferric oxyhydroxide (and food) was administered $2 \mathrm{~h}$ before each of the medications, the $\mathrm{C}_{\max }$ values of losartan, furosemide, omeprazole and digoxin were increased (upper bound $90 \%$ CIs were outside the bioequivalence range) relative to those in the absence of sucroferric oxyhydroxide.

$T_{\max }$ and $t_{1 / 2}$

The $\mathrm{T}_{\max }$ value of losartan was significantly reduced when sucroferric oxyhydroxide was administered with the medication relative to the value obtained in the absence of sucroferric oxyhydroxide (Table 4). The $\mathrm{T}_{\max }$ values of losartan, EXP 3174, furosemide, omeprazole, digoxin and $\mathrm{R}$ - and S-warfarin were also significantly reduced when sucroferric oxyhydroxide (and food) was administered $2 \mathrm{~h}$ before the medications.

A significant decrease in the $t_{1 / 2}$ of losartan and EXP 3174 and an increase in $t_{1 / 2}$ of furosemide were observed when sucroferric oxyhydroxide (and food) was administered with the medications, as compared to when medications were administered in the absence of sucroferric oxyhydroxide (Table 4). 
Table 3 Effect of sucroferric oxyhydroxide on test drug pharmacokinetic exposure (geometric LS means), based on $\mathrm{AUC}_{0-24}, \mathrm{AUC}_{0-\infty}$ and $\mathrm{C}_{\max }$

\begin{tabular}{llll}
\hline PK parameter (units) & $\begin{array}{l}\text { No sucroferric } \\
\text { oxyhydroxide; test drug } \\
\text { with food (Schedule 2) }\end{array}$ & $\begin{array}{l}\text { Sucroferric oxyhydroxide } \\
\text { and test drug with food } \\
\text { (Schedule 1) }\end{array}$ & $\begin{array}{l}\text { Sucroferric oxyhydroxide } \\
\text { with food; test drug 2 h } \\
\text { later (Schedule 3) }\end{array}$ \\
\hline
\end{tabular}

Geometric LS mean ratio (90\% CI);

Schedule 1/Schedule 2 Schedule 3/Schedule 2

\section{Losartan}

$\operatorname{AUC}_{0-24}(\mathrm{~h} \mathrm{ng} / \mathrm{ml})^{\mathrm{a}}$
$\operatorname{AUC}_{0-\infty}(\mathrm{h} \mathrm{ng} / \mathrm{ml})^{\mathrm{a}}$
$\mathrm{C}_{\max }(\mathrm{ng} / \mathrm{ml})$

782.00

786.87

313.90

EXP 3174

$\begin{array}{ll}\mathrm{AUC}_{0-24}(\mathrm{~h} \mathrm{ng} / \mathrm{ml})^{\mathrm{a}} & 4,104.09 \\ \mathrm{AUC}_{0-\infty}(\mathrm{h} \mathrm{ng} / \mathrm{ml})^{\mathrm{a}} & 4,500.93 \\ \mathrm{C}_{\text {max }}(\mathrm{ng} / \mathrm{ml}) & 631.26\end{array}$

Furosemide

$\operatorname{AUC}_{0-24}(\mathrm{~h} \mathrm{ng} / \mathrm{ml})^{\mathrm{a}}$
$\operatorname{AUC}_{0-\infty}(\mathrm{h} \mathrm{ng} / \mathrm{ml})^{\mathrm{a}}$
$\mathrm{C}_{\max }(\mathrm{ng} / \mathrm{ml})$

497.44

Omeprazole

$\begin{array}{lr}\mathrm{AUC}_{0-8}(\mathrm{~h} \mathrm{ng} / \mathrm{ml})^{\mathrm{a}} & 1,295.43 \\ \mathrm{AUC}_{0-\infty}(\mathrm{h} \mathrm{ng} / \mathrm{ml})^{\mathrm{a}} & 1,620.82 \\ \mathrm{C}_{\text {max }}(\mathrm{ng} / \mathrm{ml}) & 571.42\end{array}$

$1,255.25$

$1,479.14$

495.34

\section{Digoxin}

$$
\begin{aligned}
& \mathrm{AUC}_{0-24}(\mathrm{~h} \mathrm{ng} / \mathrm{ml})^{\mathrm{a}} \\
& \mathrm{AUC}_{0-\infty}(\mathrm{h} \mathrm{ng} / \mathrm{ml})^{\mathrm{a}} \\
& \mathrm{C}_{\max }(\mathrm{ng} / \mathrm{ml})
\end{aligned}
$$$$
11.11
$$$$
30.55
$$

R-warfarin

$$
\begin{array}{lr}
\mathrm{AUC}_{0-24}(\mathrm{~h} \mathrm{ng} / \mathrm{ml})^{\mathrm{a}} & 19,061.33 \\
\mathrm{AUC}_{0-\infty}(\mathrm{h} \mathrm{ng} / \mathrm{ml})^{\mathrm{a}} & 68,552.25 \\
\mathrm{C}_{\text {max }}(\mathrm{ng} / \mathrm{ml}) & 1,084.79
\end{array}
$$

$19,049.28$

$68,867.47$

$1,084.43$

$15,801.93$

742.27
743.86
382.76

$4,071.18$

$4,399.30$

659.77

$2,003.20$

2,103.79

682.49

$1,491.18$

$1,592.40$

741.80

12.13

31.02

1.98

$19,726.65$

$69,945.84$

$1,179.19$

$16,202.49$
0.989 (0.927, 1.056)

0.949 (0.889, 1.013)

$0.985(0.923,1.050)$

0.945 (0.886, 1.009)

0.927 (0.761, 1.129)

$1.219(1.000,1.487)$

0.955 (0.857, 1.065)

$0.992(0.889,1.107)$

0.941 (0.847, 1.046)

0.977 (0.878, 1.088)

$0.933(0.808,1.077)$

1.045 (0.904, 1.208)

$0.889(0.844,0.935)$

$0.961(0.913,1.012)$

$0.940(0.886,0.998)$

$0.974(0.920,1.031)$

$0.850(0.766,0.944)$

$1.166(1.050,1.296)$

$0.969(0.869,1.080)$

$1.151(1.034,1.282)$

$0.913(0.830,1.003)$

$0.982(0.903,1.069)$

$0.867(0.754,0.996)$

$1.298(1.130,1.492)$

$1.090(1.014,1.171)$

$1.091(1.015,1.173)$

$1.074(0.998,1.155)$

$1.016(0.944,1.093)$

$1.109(0.995,1.236)$

$1.218(1.093,1.356)$

$0.999(0.981,1.018)$

$1.035(1.016,1.054)$

$1.005(0.975,1.035)$

$1.020(0.991,1.051)$

$1.000(0.970,1.030)$

$1.087(1.055,1.120)$

$0.998(0.976,1.021)$

$1.023(1.000,1.047)$ 
Table 3 continued

\begin{tabular}{lllll}
\hline PK parameter (units) & $\begin{array}{l}\text { No sucroferric } \\
\text { oxyhydroxide; test drug } \\
\text { with food (Schedule 2) }\end{array}$ & $\begin{array}{l}\text { Sucroferric oxyhydroxide } \\
\text { and test drug with food } \\
\text { (Schedule 1) }\end{array}$ & $\begin{array}{l}\text { Sucroferric oxyhydroxide } \\
\text { with food; test drug 2 h } \\
\text { later (Schedule 3) }\end{array}$ & $\begin{array}{l}\text { Geometric LS mean ratio } \\
(90 \% \text { CI); } \\
\text { Schedule 1/Schedule 2 } \\
\text { Schedule 3/Schedule 2 }\end{array}$ \\
\hline $\mathrm{AUC}_{0-\infty}(\mathrm{h} \mathrm{ng} / \mathrm{ml})^{\mathrm{a}}$ & $46,174.66$ & $45,824.90$ & $46,277.24$ & $0.992(0.960,1.026)$ \\
$\mathrm{C}_{\max }(\mathrm{ng} / \mathrm{ml})$ & $1,033.36$ & $1,035.07$ & $1,168.21$ & $1.002(0.969,1.036)$ \\
& & & $1.002(0.965,1.040)$ \\
$1.130(1.088,1.174)$
\end{tabular}

$L S$ least squares, $P K$ pharmacokinetic, $A U C$ area under the curve

${ }^{a}$ Although $\mathrm{AUC}_{0-24}$ was planned, omeprazole levels were below the limit of quantitation in all subjects by $8-12 \mathrm{~h}$; therefore, $\mathrm{AUC}_{0-8}$ was calculated instead of $\mathrm{AUC}_{0-24}$

Table 4 Effect of sucroferric oxyhydroxide on test drug pharmacokinetic exposure (median difference), based on $\mathrm{T}_{\max }$ and $\mathrm{t}_{1 / 2}$

\begin{tabular}{|c|c|c|c|c|c|}
\hline $\begin{array}{l}\text { PK } \\
\text { parameter } \\
\text { (units) }\end{array}$ & $\begin{array}{l}\text { No sucroferric } \\
\text { oxyhydroxide; test drug } \\
\text { with food (Schedule 2) }\end{array}$ & $\begin{array}{l}\text { Sucroferric } \\
\text { oxyhydroxide and test } \\
\text { drug with food (Schedule 1) }\end{array}$ & $\begin{array}{l}\text { Sucroferric oxyhydroxide } \\
\text { with food; test drug } 2 \mathrm{~h} \\
\text { later (Schedule 3) }\end{array}$ & $\begin{array}{l}\text { Median difference }(90 \% \mathrm{CI}) \\
\text { Schedule } 1 / \text { Schedule } 2 \\
\text { Schedule } 3 / \text { Schedule } 2\end{array}$ & $\begin{array}{l}\text { Wilcoxon } \\
\text { signed rank } \\
\text { p value }\end{array}$ \\
\hline \multicolumn{6}{|l|}{ Losartan } \\
\hline $\mathrm{T}_{\max }(\mathrm{h})$ & 3.00 & 2.50 & 2.00 & $\begin{array}{l}-1.00(-1.25,-0.50) \\
-1.00(-1.50,-0.74)\end{array}$ & $\begin{array}{l}0.0021 \\
<0.0001\end{array}$ \\
\hline $\mathrm{t}_{1 / 2}(\mathrm{~h})$ & 2.08 & 1.83 & 1.97 & $\begin{array}{l}-0.25(-0.46,-0.08) \\
-0.12(-0.47,0.13)\end{array}$ & $\begin{array}{l}0.0154 \\
0.4774\end{array}$ \\
\hline \multicolumn{6}{|l|}{ EXP 3174} \\
\hline $\mathrm{T}_{\max }(\mathrm{h})$ & 5.00 & 4.52 & 4.00 & $\begin{array}{l}-0.50(-1.00,0.00) \\
-1.00(-1.50,-0.50)\end{array}$ & $\begin{array}{l}0.0810 \\
0.0019\end{array}$ \\
\hline $\mathrm{t}_{1 / 2}(\mathrm{~h})$ & 6.94 & 6.55 & 6.87 & $\begin{array}{l}-0.35(-0.63,0.09) \\
-0.19(-0.50,0.13)\end{array}$ & $\begin{array}{l}0.0415 \\
0.3248\end{array}$ \\
\hline \multicolumn{6}{|l|}{ Furosemide } \\
\hline $\mathrm{T}_{\max }(\mathrm{h})$ & 3.00 & 3.00 & 2.00 & $\begin{array}{l}-0.45(-0.75,0.00) \\
-1.25(-1.72,-0.75)\end{array}$ & $\begin{array}{l}0.1004 \\
<0.0001\end{array}$ \\
\hline $\mathrm{t}_{1 / 2}(\mathrm{~h})$ & 2.88 & 5.77 & 2.84 & $\begin{array}{l}2.02(0.80,3.23) \\
0.22(-1.31,1.84)\end{array}$ & $\begin{array}{l}0.0044 \\
0.7003\end{array}$ \\
\hline \multicolumn{6}{|c|}{ Omeprazole } \\
\hline $\mathrm{T}_{\max }(\mathrm{h})$ & 4.00 & 5.00 & 2.50 & $\begin{array}{c}0.50(0.00,1.00) \\
-1.75(-2.25,-1.25)\end{array}$ & $\begin{array}{l}0.2142 \\
<0.0001\end{array}$ \\
\hline $\mathrm{t}_{1 / 2}(\mathrm{~h})$ & 1.00 & 1.09 & 0.92 & $\begin{array}{r}0.00(-0.13,0.18) \\
-0.01(-0.11,0.06)\end{array}$ & $\begin{array}{l}1.0000 \\
0.6889\end{array}$ \\
\hline \multicolumn{6}{|l|}{ Digoxin } \\
\hline $\mathrm{T}_{\max }(\mathrm{h})$ & 1.50 & 2.00 & 1.50 & $\begin{array}{c}0.02(0.00,0.25) \\
-0.50(-0.50,-0.25)\end{array}$ & $\begin{array}{l}0.2445 \\
0.0006\end{array}$ \\
\hline $\mathrm{t}_{1 / 2}(\mathrm{~h})$ & 39.52 & 38.12 & 35.93 & $\begin{array}{l}-2.13(-5.02,1.26) \\
-2.80(-5.32,-0.15)\end{array}$ & $\begin{array}{l}0.4022 \\
0.0854\end{array}$ \\
\hline \multicolumn{6}{|l|}{$\mathrm{R}$-warfarin } \\
\hline $\mathrm{T}_{\max }(\mathrm{h})$ & 3.08 & 4.00 & 2.00 & $\begin{array}{c}0.25(-0.50,0.75) \\
-1.50(-2.25,-1.00)\end{array}$ & $\begin{array}{l}0.7835 \\
<0.0001\end{array}$ \\
\hline $\mathrm{t}_{1 / 2}(\mathrm{~h})$ & 48.60 & 48.43 & 48.31 & $\begin{array}{r}0.40(-0.95,1.83) \\
-0.32(-1.57,0.99)\end{array}$ & $\begin{array}{l}0.5520 \\
0.6775\end{array}$ \\
\hline \multicolumn{6}{|l|}{ S-warfarin } \\
\hline $\mathrm{T}_{\max }(\mathrm{h})$ & 3.00 & 3.51 & 1.50 & $\begin{array}{c}0.25(-0.25,0.51) \\
-1.25(-1.50,-1.00)\end{array}$ & $\begin{array}{l}0.4823 \\
<0.0001\end{array}$ \\
\hline$t_{1 / 2}(h)$ & 40.10 & 40.55 & 40.44 & $\begin{array}{r}0.30(-0.32,0.99) \\
-0.74(-1.59,0.30)\end{array}$ & $\begin{array}{l}0.3817 \\
0.2612\end{array}$ \\
\hline
\end{tabular}

$C I$ confidence interval, $P K$ pharmacokinetic 
Safety

Across the five studies, 126/210 (60.0\%) subjects experienced treatment-emergent adverse events (TEAEs). Overall, 82/210 (39.1\%) subjects reported treatment-related TEAEs. These were reported by an average of $22.9 \%$ ( $\mathrm{n}=47 / 205)$ of subjects during 'Schedule 1' dosing, $5.0 \%(\mathrm{n}=10 / 199)$ during 'Schedule 2' dosing, and $22.0 \%(\mathrm{n}=44 / 200)$ during 'Schedule 3' dosing. GI events were the most common class of treatment-related TEAE, occurring in an average of $30.0 \%(n=63 / 210)$ of subjects across studies. Of these, discolored feces were the most frequently reported treatment-related GI event and occurred in an average of $20.0 \%$ of subjects across the studies.

One subject in the warfarin study developed a TEAE (rhabdomyolysis) that was considered to be both serious and severe, but unrelated to study treatment. The subject reported an unplanned period of strenuous physical activity a few days prior to complaining of muscle soreness that was associated with elevated muscle enzymes. The event resolved spontaneously within a few days. There were no deaths across the studies.

\section{Discussion}

The data reported here indicate that sucroferric oxyhydroxide does not affect systemic exposure (based on $\mathrm{AUC}_{0-\infty}$ ) to any of the drugs tested in this study when they are administered with sucroferric oxyhydroxide or $2 \mathrm{~h}$ after sucroferric oxyhydroxide. Similarly, sucroferric oxyhydroxide does not affect systemic exposure (based on $\mathrm{AUC}_{0-24}$ ) for any of the drugs, irrespective of whether sucroferric oxyhydroxide was administered with the medication or $2 \mathrm{~h}$ earlier. However, no $\mathrm{AUC}_{0-24}$ values could be obtained for omeprazole because drug levels were below the limit of quantification in all subjects by $8-12 \mathrm{~h}$ but $\mathrm{AUC}_{0-\infty}$ values were within the bioequivalence criteria. Taken together, the results indicate that sucroferric oxyhydroxide may be administered concomitantly with losartan, furosemide, omeprazole, digoxin or warfarin without the need to adjust drug dosages or administration regimen.

The study data also suggest that the $C_{\max }$ values of losartan, furosemide, omeprazole and digoxin are sensitive to the timing of sucroferric oxyhydroxide administration. When losartan, furosemide, omeprazole and digoxin were administered $2 \mathrm{~h}$ after sucroferric oxyhydroxide (and food), but $\geq 1 \mathrm{~h}$ before the next meal, their $\mathrm{C}_{\max }$ values were increased relative to those observed when the medications were given with food in the absence of sucroferric oxyhydroxide. It is possible that these differences are caused by a 'food effect'. $\mathrm{C}_{\max }$ values for furosemide, omeprazole and digoxin have been observed to decrease when these agents are administered with food [14-16]. However, a direct effect of sucroferric oxyhydroxide on the rate of absorption of these compounds cannot be excluded because sucroferric oxyhydroxide was associated with decreased $C_{\max }$ values for losartan (although the $\mathrm{C}_{\max }$ of its active metabolite EXP 3174 was unaffected), furosemide and omeprazole when given with the drugs relative to $C_{\max }$ values in the absence of sucroferric oxyhydroxide-food being given with the agents in both cases. A similar action may underlie the observed effects of sucroferric oxyhydroxide on the $T_{\max }$ and $t_{1 / 2}$ of some agents investigated in these studies. However, given that the overall exposure for these agents was largely unaffected by sucroferric oxyhydroxide, as discussed above, these changes are unlikely to be clinically significant.

Sucroferric oxyhydroxide was generally well tolerated when administered with the medications in healthy subjects. The TEAEs related to treatment were almost entirely nonsevere and consistent with the known safety profile of sucroferric oxyhydroxide $[7,9,10]$. Discolored feces were a common GI-related event among subjects after receiving sucroferric oxyhydroxide. Discolored feces are a known effect of sucroferric oxyhydroxide as well as other iron-based phosphate binders $[9,17]$ and iron-based products in general.

In previous clinical studies, sucroferric oxyhydroxide was effective at reducing serum phosphorus concentrations in CKD patients undergoing dialysis, and showed similar efficacy and tolerability to sevelamer [9, 10], while having a lower tablet burden [10]. Therefore, sucroferric oxyhydroxide may represent a new treatment option for CKD dialysis patients, with the potential for improved adherence and low risk of DDIs with the medications investigated in these studies.

Acknowledgments This manuscript was prepared with the editorial assistance of AXON Communications, Richmond, UK. This manuscript and the five Phase I pharmacokinetic studies mentioned therein were sponsored by Vifor (International) AG, St Gallen, Switzerland.

Conflict of interest EC and VK are employees of Vifor. EC was Clinical Development Lead of the studies reported in the manuscript. VK was Sponsor Contact and author of the clinical study reports for the studies reported in the manuscript. SW was Coordinating Investigator for the warfarin study. PW was Coordinating Investigator for the losartan, furosemide, omeprazole and digoxin studies.

Ethical standard Study documentation was approved by an Institutional Review Board/Independent Ethics Committee. The study was performed in accordance with the Declaration of Helsinki and subsequent amendments. Informed consent was obtained from all participants.

Open Access This article is distributed under the terms of the Creative Commons Attribution License which permits any use, distribution, and reproduction in any medium, provided the original author(s) and the source are credited. 


\section{References}

1. Hruska KA, Mathew S (2011) The roles of the skeleton and phosphorus in the CKD mineral bone disorder. Adv Chronic Kidney Dis 18:98-104

2. Block GA (2001) Control of serum phosphorus: implications for coronary artery calcification and calcific uremic arteriolopathy (calciphylaxis). Curr Opin Nephrol Hypertens 10:741-747

3. Block GA, Klassen PS, Lazarus JM, Ofsthun N, Lowrie EG, Chertow GM (2004) Mineral metabolism, mortality, and morbidity in maintenance hemodialysis. J Am Soc Nephrol 15:2208-2218

4. Palmer SC, Hayen A, Macaskill P et al (2011) Serum levels of phosphorus, parathyroid hormone, and calcium and risks of death and cardiovascular disease in individuals with chronic kidney disease: a systematic review and meta-analysis. JAMA 305:1119-1127

5. Kanbay M, Goldsmith D, Akcay A, Covic A (2009) Phosphatethe silent stealthy cardiorenal culprit in all stages of chronic kidney disease: a systematic review. Blood Purif 27:220-230

6. Tentori F, Blayney MJ, Albert JM et al (2008) Mortality risk for dialysis patients with different levels of serum calcium, phosphorus, and PTH: the Dialysis Outcomes and Practice Patterns Study (DOPPS). Am J Kidney Dis 52:519-530

7. Geisser P, Philipp E (2010) PA21: a novel phosphate binder for the treatment of hyperphosphatemia in chronic kidney disease. Clin Nephrol 74:4-11

8. Hergesell O, Ritz E (1999) Stabilized polynuclear iron hydroxide is an efficient oral phosphate binder in uraemic patients. Nephrol Dial Transplant 14:863-867
9. Wüthrich RP, Chonchol M, Covic A, Gaillard S, Chong E, Tumlin JA (2013) Randomized clinical trial of the iron-based phosphate binder PA21 in hemodialysis patients. Clin J Am Soc Nephrol 8:280-289

10. Floege J, Ketteler M, Rastogi A et al (2012) Efficacy and safety of PA21 in hyperphosphatemic CKD patients on dialysis. J Am Soc Nephrol 23:abstract SA-PO1103

11. Sprague S, Floege J, Covic A et al (2013) Efficacy of PA21, a novel iron-based phosphate binder, maintained to 52 weeks in dialysis patients with hyperphosphatemia. J Am Soc Nephrol 24:abstract TH-OR027

12. Rifkin DE, Winkelmayer WC (2010) Medication issues in older individuals with CKD. Adv Chronic Kidney Dis 17:320-328

13. Mason NA, Bakus JL (2010) Strategies for reducing polypharmacy and other medication-related problems in chronic kidney disease. Semin Dial 23:55-61

14. Johnson BF, O'Grady J, Sabey GA, Bye C (1978) Effect of a standard breakfast on digoxin absorption in normal subjects. Clin Pharmacol Ther 23:315-319

15. Vaz-da-Silva M, Loureiro AI, Nunes T et al (2005) Bioavailability and bioequivalence of two enteric-coated formulations of omeprazole in fasting and fed conditions. Clin Drug Investig 25:391-399

16. Beermann B, Midskov C (1986) Reduced bioavailability and effect of furosemide given with food. Eur J Clin Pharmacol 29:725-727

17. Sinsakul M, Sika M, Koury M et al (2012) The safety and tolerability of ferric citrate as a phosphate binder in dialysis patients. Nephron Clin Pract 121:c25-c29 